\title{
PENGEMBANGAN BUKU KERJA MEDIA PEMBELAJARAN IPA BERBASIS KONTEKSTUAL SEBAGAI PENUNJANG MATA KULIAH MEDIA PEMBELAJARAN
}

\author{
Herowati $^{1}$, Lutfiana Fazad Azizah ${ }^{2}$ \\ Universitas Wiraraja ${ }^{1,2}$ \\ herowati.fkip@wiraraja.ac.id ${ }^{1}$, lutfianafazat@wiraraja.ac.id ${ }^{2}$
}

\begin{abstract}
ABSTRAK
Tujuan penelitian ini adalah untuk menghasilkan buku kerja media pembelajaran IPA berbasis kontekstual sebagai penunjang mata kuliah media pembelajaran ditinjau dari validasi ahli. Model penelitian yang digunakan adalah model penelitian pengembangan 4D (four D) yang terdiri dari 4 tahapan yaitu: Define (Pendefinisian), Design (Perancangan), Develope (Pengembangan), dan Disseminate (Penyebaran). Penelitian ini terbatas hanya pada tahap define, design, dan develope. Hasil penelitian yang didapatkan yaitu kelayakan buku kerja media pembelajaran IPA berbasis kontekstual didapatkan dari hasil validasi aspek materi 96\%, desain memperoleh rata-rata persentase $98 \%$ dan respon mahasiswa 95\% dengan kategori sangat layak sehingga buku kerja media pembelajaran IPA berbasis kontekstual dapat digunakan.
\end{abstract}

Kata Kunci: Buku kerja, media pembelajaran IPA, Berbasis Kontekstual

\section{ABSTRACT}

The purpose of this research is to produce a contextual based science learning media workbooks as a support for learning media courses in terms of expert validation. The research model used is a 4D (four D) development research model consisting of 4 stages, namely: Define, Design, Develope, and Disseminate. This research is limited to the define, design, and develope stages. The results obtained are the feasibility of a contextual science-based learning media workbook obtained from the validation of the material aspect $96 \%$, the design obtained an average percentage of $98 \%$ and $95 \%$ student responses with a very appropriate category so that the contextual-based science learning media workbook can be used.

Keywords: Workbook, Science learning media, Contextual Based

\section{PENDAHULUAN}

Mata kuliah media pembelajaran merupakan salah satu mata kuliah wajib dalam kurikulum Prodi Pendidikan IPA di Universitas Wiraraja. Capaian akhir mata kuliah media pembelajaran pada aspek kognitif adalah mahasiswa memiliki kemampuan/ kompetensi menjelaskan pengertian, jenis/klasifikasi, fungsi, dasar-dasar pengembangan media pembelajaran. Capaian akhir pembelajaran yang kedua adalah aspek psikomotor yaitu mahasiswa mampu merancang, memilih dan memproduksi media pembelajaran IPA dengan memanfaatkan lingkungan sekitar (kontekstual) dan/atau berbasis TIK. Capaian akhir pembelajaran yang ketiga adalah aspek afektif yaitu mahasiswa memiliki sikap bertanggung jawab dalam mengembangkan media pembelajaran IPA yang praktis, efisien, dan aman bagi peserta didik. Pencapaian akhir kegiatan pembelajaran tersebut, diperlukan pembekalan kepada mahasiswa akan kemampuan-kemampuan yang diperlukan 
terutama dalam merancang, memilih dan memproduksi media pembelajaran IPA dengan memanfaatkan lingkungan sekitar (kontekstual) dan/atau berbasis TIK sehingga dengan pembekalan kompetensi tersebut diharapkan mahasiswa mampu merancang, memilih dan memproduksi pembelajaran berbasis kontekstual dan/atau berbasis TIK yang layak digunakan (Focus group diskusi Program Studi Pendidikan IPA Universitas Wiraraja, 2017).

Hasil observasi pada pembelajaran mata kuliah pengembangan media pembelajaran adalah sebagai berikut: 1) kegiatan perkulihan dilakukan dengan metode diskusi informasi menggunakan beberapa referensi buku media pembelajaran; 2) tugas pengembangan media pembelajaran IPA include dalam kegiatan perkuliahaan dengan menggunakan media cetak pendukung kegiatan perkuliahan yaitu petunjuk praktikum media pembelajaran, yang didalamnya berisikan kegiatan mahasiswa dengan capaian kompetensi agar mahasiswa mampu mengembangankan media pembelajaran IPA berbasis TIK. (3) kegiatan pengembangan media pembelajaran berbasis TIK juga memanfaatkan sarana dan lingkungan sekitar sebagai media mengembangkan media pembelajaran IPA tingkat SD dan SMP yang syarat dengan pembelajaran kontektual dan dekat dengan kehidupan sehari- hari mahasiswa sehingga dalam kegiatan pembelajaran bahan ajar yang digunakan kurang mengembangkan potensi mahasiswa dengan maksimal khususnya kompetensi dalam mengembangkan media berbasis kontekstual. Mahasiswa Prodi Pendidikan IPA Universitas Wiraraja sebagai calon guru IPA membutuhkan kompetensi dalam mengembangkan media pembelajaran IPA baik pada media berbasis kontektual dan berbasis TIK dalam dunia kerja agar mahasiswa dapat menentukan atau memilih media pembelajaran yang sesuai atau tidak sesuai di sekolah baik di tingkat SD atau SMP berdasarkan sarana pendukung dan lingkungan sekolah (kontekstual), karena pemilihan media pembelajaran tidak dapat disamaratakan di seluruh sekolah, karena kontekstualitas, kemampuan mahasiswa, sarana pendukung dan lingkungan sekolah yang berbeda-beda. Salah satu tinjauan yang sangat penting dalam kegiatan mata kuliah media pembelajaran adalah perlunya suatu kegiatan pembelajaran yang menekankan pada proses pembelajaran yang menyenangkan dan membangkitkan proses kreativitas untuk meningkatkan kemampuan mahasiswa terutama dalam merancang, memilih dan memproduksi media pembelajaran IPA berbasis kontekstual dan/atau berbasis TIK. Tujuan dari pengembangan media pembelajaran adalah unruk menghasilkan media yang dapat dipakai untuk mencapai tujuan pembelajaran dengan efisien dan efektif (Dwiyogo, 2013). Istilah pendidikan pada dasarnya merupakan suatu proses komunikasi dan informasi dari pendidik kepada peserta dididk ysng berisi informasi- informasi pendidiikan, yang terdiri dari pendidik sebagai fasilitator dan sebagai bagian dari sumber informasi, peserta didik sebagai orang yang belajar, serta media sebagai sarana penyaji ide, gagasan, dan materi pendidikan (Darmawan, 2014).

Pengembangan Buku Kerja Media Pembelajaran IPA Berbasis Kontekstual Sebagai Penunjang Mata Kuliah Media Pembelajaran dapat menjadi salah satu alternative untuk mengatasi masalah agar kompetensi mahasiswa dalam merancang, memilih dan memproduksi media pembelajaran IPA berbasis kontekstual berkembang maksimal. Hasil penelitian dari (Darman, Wibowo and Putra, 2017) judul pengembangan buku kerja fisika berbasis kontekstual pada konsep suhu dan kalor menyatakan bahwa media buku kerja yang dikembangkan memenuhi kriteria valid atau layak digunakan 
dengan nilai kevalidan 3, 50. Tingkat kepraktisan memiliki kategori praktis dan sangat praktis baik dari guru dan mahasiswa dengan persentase $87 \%$ dan $90 \%$. Persentase tersebut menunjukkan bahwa buku kerja fisika berbasis kontekstual pada konsep suhu dan kalor memenuhi kriteria valid.

\section{METODOLOGI PENELITIAN Model Penelitian dan Pengembangan}

Model penelitian yang digunakan adalah model penelitian pengembangan 4D (four D) yang dikembangkan oleh (Thiagarajan, Semmel and Semmel, 1974) yang terdiri dari 4 tahap yaitu Define (Pendefinisian), Design (Perancangan), Develope (Pengembangan), dan Disseminate (Penyebaran), namun penelitian ini hanya sampai pada tahapan ketiga yaitu Develope (Developmental testing) dikarenakan keterbatasan waktu, tenaga, dan biaya.

Tahap define dilakukan dengan kegiatan berikut:

1) Analisis awal dan akhir, yaitu menetapkan permasalahan dasar dalam proses pembelajaran. Tahap ini melalui proses observasi, wawancara, dan penyebaran angket yang diberikan kepada mahasiswa Prodi IPA Universitas Wiraraja.

2) Analisis tugas, yaitu dilakukan dengan kegiatan analisis deskripsi mata kuliah (konsep), capaian pembelajaran dan capaian akhir pembelajaran.

3) Analisis Konsep (Concept Analysis)

Analisis konsep dilakukan untuk mengetahui konsep utama dalam satuan pembelajaran yang diperinci dalam sistematika materi pembelajaran (Thiagarajan, Semmel and Semmel, 1974). Analisis konsep meliputi analisis capaian pembelajaran, capaian akhir pembelajaran, serta materi pembelajaran.

4) Analisis Capaian Pembelajaran (Specifying Instructional Objectives)
Perumusan capaian pembelajaran merupakan kegiatan perubahan dari analisis tugas dan analisis konsep melalui tahapan yang berulang hingga menjadi pernyataan dalam capaian pembelajaran (Thiagarajan, Semmel and Semmel, 1974). Kegiatan ini meliputi analisis analisis capaian pembelajaran, capaian akhir pembelajaran.

Tahap design berisi kegiatan untuk membuat rancangan terhadap produk yang telah ditetapkan. Tahap ini terdiri dari kegiatan penyusunan standar tes, pemilihan media, pemilihan format, dan rancangan awal.

1) Penyusunan Standar Tes (CriterionTest Construction)

Penyusunan standar tes merupakan tahap penyusunan instrumen untuk mengetahui efektivitas produk yang dikembangkan (Thiagarajan, Semmel and Semmel, 1974). Penelitian ini menggunakan instrumen berupa angket kebutuhan mahasiswa terhadap media penunjang kegiatan belajar (tugas) pada mata kuliah media pembelajaran.

2) Pemilihan Media (Media Selection)

Pemilihan media merupakan tahap penyesuaian antara analisis mahasiswa, analisis tugas, analisis konsep, perumusan capaian akhir pembelajaran, serta penyusunan standar tes dalam menentukan media yang sesuai dengan hasil pendeskripsian informasi dalam pembelajaran (Thiagarajan, Semmel and Semmel, 1974). Media yang dikembangkan berupa buku kerja media pembelajaran IPA berbasis kontekstual.

3) Pemilihan Format (Format Selection) Tahap pemilihan format dilakukan kegiatan menetapkan format media pembelajaran yang akan dikembangkan (Thiagarajan, Semmel and Semmel, 1974). Format buku kerja media pembelajaran IPA berbasis kontekstual diadaptasi dari (Maudiarti, 
2007), mengemukakan bahwa bagianbagian dari buku kerja yaitu: kompetensi, kiat-kiat belajar, catatan, latihan dan tugas, serta tindak lanjut..

4) Rancangan Awal (Initial Design)

Rancangan awal ini merupakan tahap menyusun desain awal produk yang akan dikembangkan (Thiagarajan, Semmel and Semmel, 1974). Rancangan buku kerja media pembelajaran IPA berbasis kontekstual dibuat menggunakan aplikasi microsoft word 2010.

Tahap development dilakukan dengan kegiatan sebagai berikut:

1) Pembuatan produk, yang terdiri dari dua tahap yaitu persiapan dan rancang bangun. Tahap persiapan yaitu mempersiapkan segala kebutuhan berupa alat dan bahan yang diperlukan dalam pembuatan produk. Tahap rancang bangun yaitu menyusun rencana desain dengan memasukkan konten/isi materi menggunakan sofware microsoft word dan pembuatan sampul menggunakan sofware adobe photoshop.

2) Validasi ahli, dilakukan dengan penilaian validator sesuai keahlian masing-masing pada produk yang dikembangkan, yaitu pada bagian isi materi dinilai oleh ahli materi sebanyak 2 orang dan validasi media dinilai oleh ahli media sebanyak 2 orang. Pada validasi materi terdapat dua indikator yang harus terpenuhi yaitu pada indikator bahasa dan materi sedangkan mada media indikator yang digunakan mengarah pada desain dari buku kerja yang dikembangkan seperti, penulisan, jenis huruf, dsb. Tahap ini juga dilakukan perbaikan atau revisi terhadap produk berdasarkan hasil penilaian dan saran oleh validator. Proses validasi ahli ini bertujuan untuk mengetahui kelayakan buku kerja yang dikembangkan pada penelitian ini.

\section{Instrumen Pengumpulan Data}

Instrument pengumpulan data yang digunakan dalam penelitian pengembangan ini ada dua. Pertama berupa lembar validasi buku kerja media pembelajaran IPA berbasis kontekstual digunakan untuk mendapatkan data kelayakan buku kerja yang dikembangkan. Data diperoleh dari hasil penilaian ahli desain dan ahli materi. Data tersebut dapat dijadikan peneliti sebagai acuan dan pedoman merevisi serta mengembangkan produk yang telah dibuat. Instrument validasi isi materi dari produk buku kerja yang dikembangkan dapat dilihat pada table 1 dan Instrument validasi design media bisa dilihat pada table 2 .

Tabel 1. Instrument Validasi Materi Buku Kerja Media Pembelajaran IPA Berbasis Kontekstual

\begin{tabular}{cl}
\hline No & \multicolumn{1}{c}{ Indikator } \\
\hline 1 & Materi sesuai dengan capaian pembelajaran mata kuliah media pembelajaran \\
\hline 2 & Materi sesuai dengan capaian akhir perkuliahan Kompetensi mata kuliah media pembelajaran \\
\hline 3 & $\begin{array}{l}\text { Materi mencerminkan jabaran capaian akhir perkuliahan mata kuliah media pembelajaran pada } \\
\text { indicator merancang, memilih dan memproduksi media pembelajaran IPA dengan memanfaatkan } \\
\end{array}$ \\
\hline 4 & Materi meliputi bidang kajian media pembelajaran untuk pembelajaran IPA berbasis kontekstual \\
\hline 5 & Kegiatan pada buku kerja sesuai dengan lingkungan sekitar (kontekstual) \\
\hline 6 & Langkah kerja jelas dan sistematis \\
\hline 7 & Sesuai dengan kaidah Bahasa Indonesia \\
\hline 8 & Kalimat memiliki struktur S-P-O-K (subjek-predikat-objek-keterangan) \\
\hline 10 & Kalimat tidak ambigu \\
\hline Konsisten dalam menulis kata
\end{tabular}

(Sumber: diadaptasi dari Mujiono dan dikembangkan oleh peneliti) 
Table 2. Instrument validasi desain Buku Kerja Media Pembelajaran IPA Berbasis Kontekstual

\begin{tabular}{cl}
\hline No & Indikator \\
\hline 1 & Gambar sampul sesuai dengan judul buku kerja media pembelajaran berbasis kontekstual \\
\hline 2 & Judul buku menjadi pusat pandang \\
\hline 3 & Warna tulisan judul buku kontras dengan warna background \\
\hline 4 & Penempatan gambar tidak mengganggu tulisan \\
\hline 5 & Penggunaan variasi huruf (bold, italic, all capital, small capital) konsisten \\
\hline 7 & Spasi teks konsisten \\
\hline 8 & Gkuran gambar sesuai dengan resolusi \\
\hline 9 & Warna gambar realistis \\
\hline 10 & Bentuk gambar realistis \\
\hline
\end{tabular}

(Sumber: diadaptasi dari Mujiono dan dikembangkan oleh peneliti)

Instrument pengumpulan data yang kedua berupa lembar angket respon digunakan untuk mengetahui respon mahasiswa terhadap buku kerja yang dikembangkan. Angket respon mahasiswa berisi pertanyaan-pertanyaan Tabel 3 Instrumen Respon Mahasiswa yang harus dipilih oleh mahasiswa dengan memberikan skor pada masingmasing pertanyaan. Instrumen respon mahasiswa terhadap produk yang dikembangkan, dapat dilihat pada Tabel 3 berikut:

\begin{tabular}{cl}
\hline No. & \multicolumn{1}{c}{ Pernyataan } \\
\hline 1 & Gambar yang digunakan memperjelas materi media pembelajaran IPA \\
\hline 2 & Contoh yang digunakan mudah ditemui dalam kehidupan sehari-hari (kontekstual) \\
\hline 3 & Penyajian materi pada buku kerja media pembelajaran IPA berbasis kontektstual sistematis \\
\hline 4 & Bahasa yang digunakan mudah dipahami \\
\hline 5 & Tampilan materi pada buku kerja media pembelajaran IPA berbasis kontektstual menarik \\
\hline 6 & $\begin{array}{l}\text { Petunjuk prak materi pada buku kerja media pembelajaran IPA berbasis kontektstual tikum mudah } \\
\text { dibawa }\end{array}$
\end{tabular}

(Sumber: diadaptasi dari Mujiono dan dikembangkan oleh peneliti)

\section{.Teknik Analisis Data}

1. Analisis Validasi Produk.

Kriteria validasi produk dapat dilihat pada Tabel 4.

$$
\text { Kriteria } \%=\frac{\mathrm{A}}{\mathrm{B}} \times 100 \%
$$

Tabel 4 Presentase kelayakan

\begin{tabular}{cc}
\hline Persentase Kelayakan & Kategori \\
\hline$<20 \%$ & Tidak layak \\
\hline $21 \%-40 \%$ & Kurang layak \\
\hline $41 \%-60 \%$ & Cukup layak \\
\hline $61 \%-80 \%$ & Layak \\
\hline $81 \%-100 \%$ & Sangat layak \\
\hline
\end{tabular}

Sumber: (Setiawan and Wiyardi, 2015)

\section{Analisis Respon Mahasiswa}

Respon mahasiswa diketahui menggunakan sebaran angket yang menggunakan skala Guttman yaitu jawaban ya dan tidak. Data respon
Keterangan:

A : Jumlah nilai yang diperoleh

B : Skor maksimal

Kriteria kelayakan dapat dilihat pada Tabel 4. 
Persentase respon mahasiswa $=$

Total skor jawaban

Kriteria respon mahasiswa dapat dilihat pada Tabel 5.

Tabel 5 Kriteria Respon Mahasiswa

\begin{tabular}{ccc} 
Kategori & $\begin{array}{c}\text { Persentase } \\
\text { Respon } \\
\text { Mahasiswa }\end{array}$ & Kriteria \\
\hline 4 & $85<\mathrm{RS} \leq 100$ & Sangat Baik \\
\hline 3 & $65<\mathrm{RS} \leq 85$ & Baik \\
\hline 2 & $45<\mathrm{RS} \leq 65$ & Cukup Baik \\
\hline 1 & $0 \leq \mathrm{RS} \leq 45$ & Tidak Baik \\
\hline
\end{tabular}

Sumber: Diadaptasi dari (Wulandari, 2017)

\section{HASIL PENELITIAN}

\section{Prapenelitian}

\section{1) Hasil Analisis Awal-Akhir}

Hasil analisis awal akhir dilakukan melalui kegiatan wawancara dan penyebaran angket kepada mahasiswa serta menganalisis media cetak pendukung kegiatan perkuliahan yaitu petunjuk praktikum media pembelajaran. Hasil wawancara dengan mahasiswa diketahui bahwa: 1) kegiatan mata kuliah media pembelajaran dilakukan dengan kegiatan diskusi informasi menggunakan beberapa referensi buku media pembelajaran; 2) mahasiswa mengerjakan tugas mata kuliah yang include dalam kegiatan perkuliahaan dengan menggunakan media cetak pendukung kegiatan perkuliahan yaitu petunjuk praktikum media pembelajaran, yang didalamnya berisikan kegiatan mahasiswa dengan capaian kompetensi agar mahasiswa mampu mengembangankan media pembelajaran IPA berbasis TIK. (3) kegiatan pengembangan media pembelajaran berbasis TIK juga memanfaatkan sarana dan lingkungan sekitar sebagai media mengembangkan media pembelajaran IPA tingkat SD dan SMP yang syarat dengan pembelajaran kontektual dan dekat dengan kehidupan sehari- hari mahasiswa sehingga dalam kegiatan pembelajaran bahan ajar yang digunakan kurang mengembangkan potensi mahasiswa dengan maksimal khususnya kompetensi dalam mengembangkan media berbasis kontekstual. Hasil analisis media cetak pendukung kegiatan perkuliahan yaitu petunjuk praktikum media pembelajaran diketahui bahwa memuat empat kegiatan yaitu desain media pembelajaran, pengembangan media pembelajaran IPA berbasis TIK "video pembelajaran IPA", kelas maya dengan edmodo, pengembangan media preparat. Secara garis besar kompetensi mahasiswa yang diharapkan adalah mahasiswa mampu merancang, memilih dan memproduksi media pembelajaran IPA berbasis TIK.

Berdasarkan hasil analisis awal dan akhir maka peneliti mengembangkan buku kerja media pembelajaran berbasis kontekstual sebagai buku pendamping untuk menunjang kegiatan/ tugas mata kuliah media pembelajaran.

\section{2) Hasil Analisis Mahasiswa}

Hasil penyebaran angket kepada 20 mahasiswa menggunakan skala guttmann dengan pilihan ya atau tidak pada semester $\mathrm{V}$ diperoleh informasi bahwa (1) mahasiswa menyukai mata kuliah media pembelajaran sebanyak $88 \%$; mahasiswa menyukai kegiatan tugas mata kuliah yang berbasis kontekstual 95\%; (3) mahasiswa menyatakan membutuhkan buku kerja media pembelajaran berbasis kontektual sebanyak 85\%. Ditinjau dari aspek pengetahuan mahasiswa prodi pendidikan IPA semester $\mathrm{V}$ berada pada tahap operasional formal dimana pada tahap ini mahaiswa mampu berpikir secara abstrak dan mampu menguji hipotesis, sehingga kegiatan tugas mata kuliah media pembelajaran yang dikaitkan dengan konteks dunia nyata yang dihubungkan dengan kehidupan sehari-hari di harapkan mahasiswa lebih mudah dalam memanfaatkan dan mengembangkan lingkungan untuk media pembelajaran IPA. 
Dengan kegiatan/ tugas yang lebih kontekstual diharapkan dapat membantu mahasiswa mengkonstruksi konsep yang lebih kekal di dalam memori jangka panjang untuk memecahkan masalah di kehidupan sehari-hari mahasiswa.

\section{3) Hasil Analisis Tugas}

Analisis tugas diperoleh dari kegiatan analisis deskripsi mata kuliah, Tabel 6. Analisis Tugas

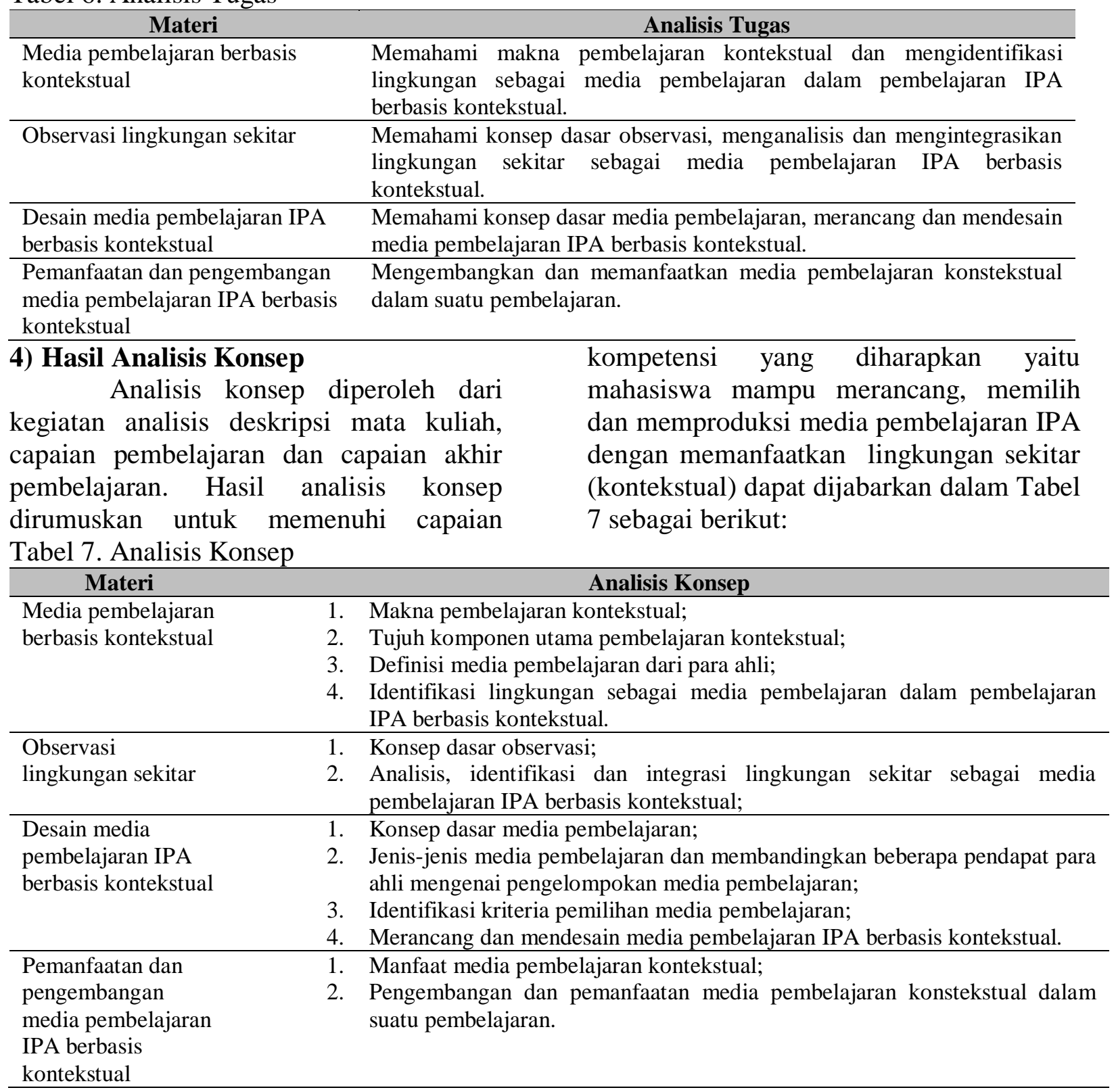

capaian pembelajaran dan capaian akhir pembelajaran. Hasil analisis tugas yang dikembangkan untuk memenuhi capaian kompetensi yang diharapkan yaitu mahasiswa mampu merancang, memilih dan memproduksi media pembelajaran IPA dengan memanfaatkan lingkungan sekitar (kontekstual) dijabarkan dalam Tabel 6 sebagai berikut: 


\section{5) Hasil Analisis Capaian Pembelajaran}

Analisis capaian pembelajaran dalam buku kerja yang akan dikembangkan dijabarkan dalam Tabel 8 sebagai berikut:

Tabel 8 Analisis Capaian Pembelajaran

\begin{tabular}{|c|c|c|}
\hline No & Materi & Capaian Pembelajaran \\
\hline 1 & $\begin{array}{l}\text { Media pembelajaran } \\
\text { berbasis kontekstual }\end{array}$ & $\begin{array}{l}\text { 1. Memahami makna pembelajaran kontekstual; } \\
\text { 2. Memahami dan mengidentifikasi ketujuh komponen utama pembelajaran } \\
\text { kontekstual; } \\
\text { 3. Memahami definisi media pembelajaran dari para ahli; } \\
\text { 4. Memahami dan mampu mengidentifikasi lingkungan sebagai media } \\
\text { pembelajaran dalam pembelajaran IPA berbasis kontekstual. }\end{array}$ \\
\hline 2 & $\begin{array}{l}\text { Observasi } \\
\text { lingkungan sekitar }\end{array}$ & $\begin{array}{l}\text { 1. Memahami konsep dasar observasi; } \\
\text { 2. Melakukan observasi secara langsung di lingkungan sekitar; } \\
\text { 3. Memahami dan menganalisis lingkungan sekitar sebagai media } \\
\text { pembelajaran IPA berbasis kontekstual; } \\
\text { 4. Mengidentifikasi hasil observasi lingkungan dalam bentuk catatan singkat; } \\
\text { 5. Mengintegrasikan lingkungan sebagai media pembelajaran IPA ke dalam } \\
\text { proses pembelajaran kontekstual. }\end{array}$ \\
\hline 3 & $\begin{array}{l}\text { Desain media } \\
\text { pembelajaran IPA } \\
\text { berbasis kontekstual }\end{array}$ & $\begin{array}{l}\text { 1. Memahami konsep dasar media pembelajaran; } \\
\text { 2. Mengetahui jenis-jenis media pembelajaran dan membandingkan beberapa } \\
\text { pendapat para ahli mengenai pengelompokan media pembelajaran; } \\
\text { 3. Memahami dan mengidentifikasi kriteria pemilihan media pembelajaran; } \\
\text { 4. Mengulang hal-hal penting dalam mendesain media pembelajaran berbasis } \\
\text { kontekstual; } \\
\text { 5. Mampu merancang dan mendesain media pembelajaran IPA berbasis } \\
\text { kontekstual. }\end{array}$ \\
\hline 4 & $\begin{array}{l}\text { Pemanfaatan dan } \\
\text { pengembangan } \\
\text { media pembelajaran } \\
\text { IPA berbasis } \\
\text { kontekstual }\end{array}$ & $\begin{array}{l}\text { 1. Mengenal berbagai pemanfaatan media pembelajaran kontekstual; } \\
\text { 2. Membandingkan pemanfaatan beberapa jenis media pembelajaran; } \\
\text { 3. Mengevaluasi kelemahan pemanfataan media pembelajaran berbasis } \\
\text { kontekstual; } \\
\text { 4. Mengembangkan dan memanfaatkan media pembelajaran konstekstual } \\
\text { dalam suatu pembelajaran. }\end{array}$ \\
\hline
\end{tabular}

\section{Deskripsi Produk}

Produk yang dikembangkan dalam deskripsi mengenai produk yang penelitian ini yaitu buku kerja media dikembangkan dapat dilihat pada Tabel 9 pembelajaran berbasis kontekstual. Adapun berikut.

Tabel 9. Deskripsi buku kerja media pembelajaran berbasis kontekstual.

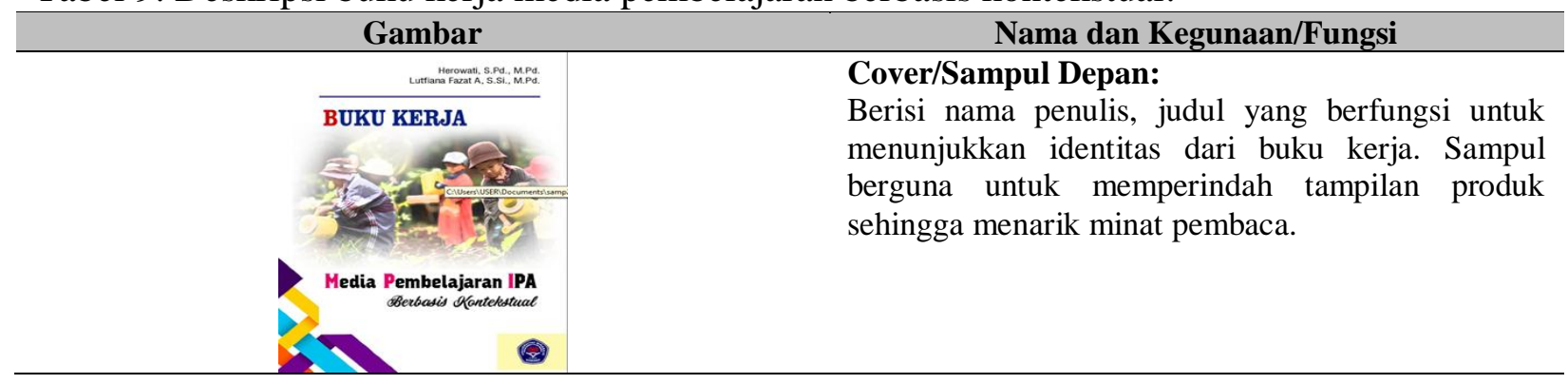




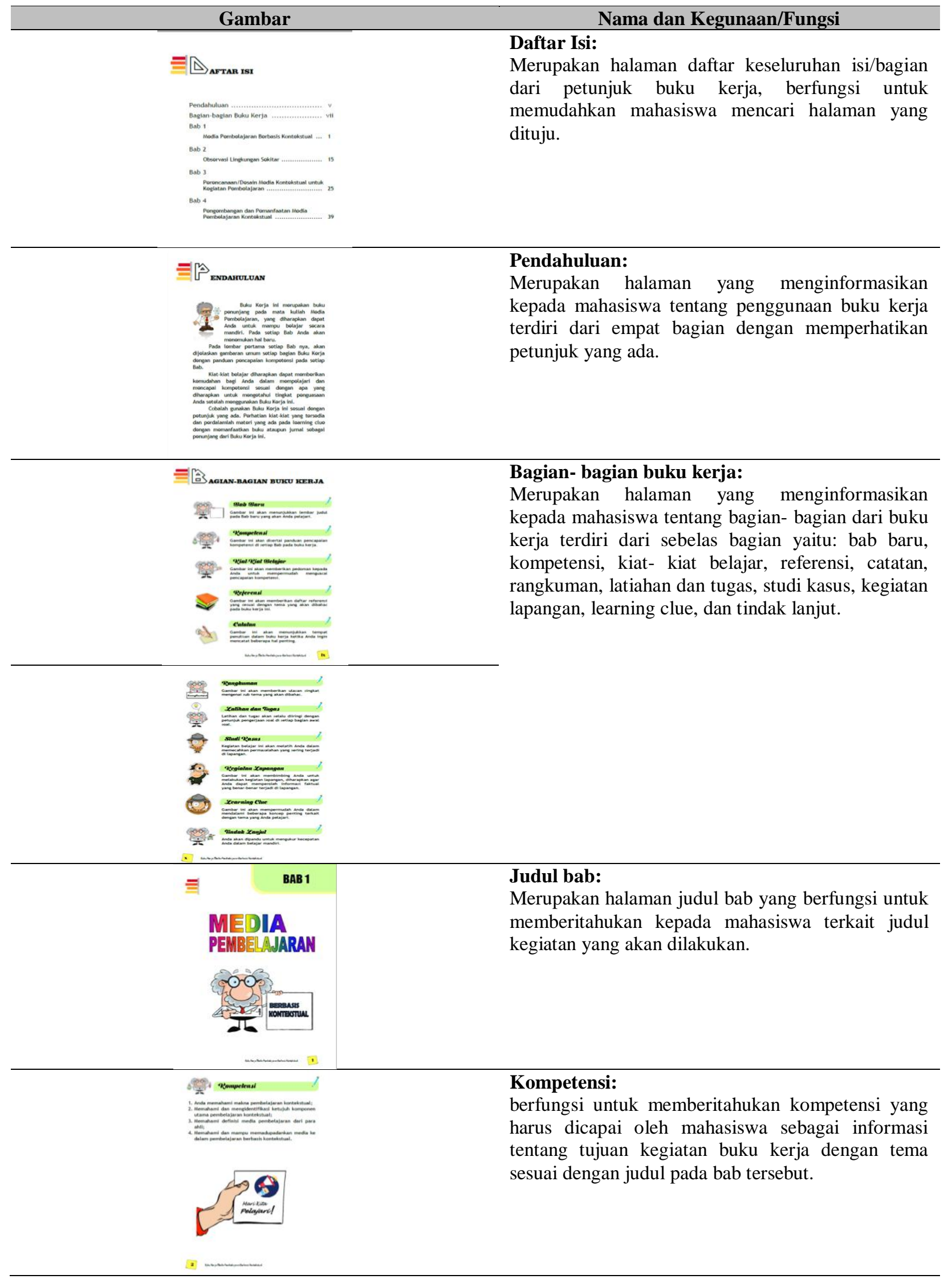




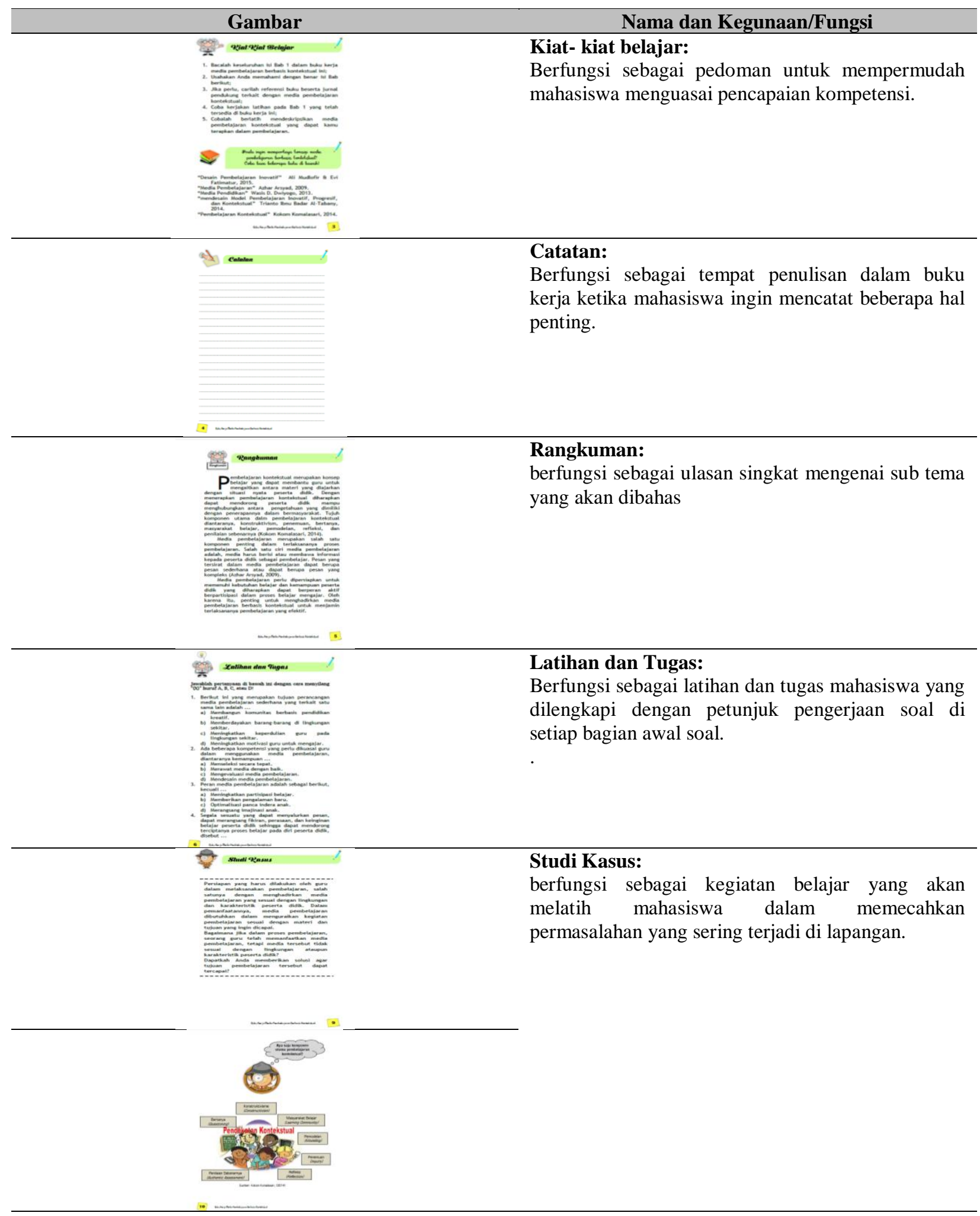




\section{Gambar}

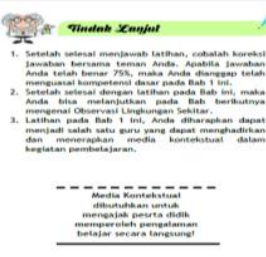

\section{Nama dan Kegunaan/Fungsi}

\section{Tindak lanjut:}

berfungsi agar mahasiswa Anda dapat mengukur kecepatan dalam belajar mandiri..

Sumber: Peneliti, diolah pada Agustus 2019

\section{Validasi Produk}

Validasi produk yang telah dikembangkan dilakukan untuk melihat kelayakan dari buku kerja media pembelajaran berbasis kontekstual yang dikembangkan oleh peneliti. Uji kelayakan produk dalam penelitian ini dilakukan terhadap empat validator sesuai dengan keahliannya masing-masing, yaitu dua Tabel 10. Data Hasil Validasi Materi buku kerja media pembelajaran berbasis kontekstual

\begin{tabular}{cccc}
\multicolumn{2}{c}{ Ahli Materi } & \multirow{2}{*}{ Bab ke- } & \multicolumn{2}{c}{ Hasil Penilaian Materi } \\
\cline { 3 - 4 } Dyah Ayu F., S.Si., M.Pd. & 1 dan 2 & Materi & Bahasa \\
\hline Ratih Yuniastri, S.Si., M.Pd & 3 dan 4 & 6 & 3,25 \\
\hline Rata-rata & & 6 & 4 \\
\hline Persentase (\%) & & $100 \%$ & 3,6 \\
\hline Kategori & & Sangat Layak & Sangat Layak
\end{tabular}

Sumber: Peneliti, diolah pada September 2019

Data hasil validasi desain buku kerja media pembelajaran berbasis kontekstual dapat dilihat pada tabel 11 sebagai berikut:

Tabel 11. Data Hasil Validasi Desain buku kerja media pembelajaran berbasis kontekstual

\begin{tabular}{cc}
\multicolumn{1}{c}{ Ahli Desain } & Hasil Penilaian Desain \\
\cline { 2 - 2 } Sri Wahyuni, S.Pd., M.Pd & Kualitas Fisik \\
\hline Nur Khamimah, S.Pd., M.Pd. & 10 \\
\hline Rata-rata & 9,5 \\
\hline Persentase (\%) & 9,75 \\
\hline Kategori & $98 \%$ \\
\hline Suri
\end{tabular}

Sumber: Peneliti, diolah pada September 2019

\section{Revisi Produk}

Revisi materi dan desain dilakukan setelah validasi produk oleh para ahli.

Tabel 12 Revisi Produk dari Para Ahli

\begin{tabular}{lcclc}
\multicolumn{1}{c}{ Nama Ahli } & Bab ke & $\begin{array}{c}\text { Bagian yang } \\
\text { Direvisi }\end{array}$ & \multicolumn{1}{c}{ Deskripsi } & $\begin{array}{c}\text { Hasil } \\
\text { Perbaikan }\end{array}$ \\
\hline $\begin{array}{l}\text { Ahli Materi Pembelajaran } \\
\begin{array}{l}\text { Kontekstual } \\
\text { (Dyah Ayu F., S.Si., M.Pd.) }\end{array}\end{array}$ & 1 dan 2 & kompetensi & $\begin{array}{l}\text { Kompetensi kegiatan kurang } \\
\text { sesuai }\end{array}$ & $\begin{array}{c}\text { Diperbaiki } \\
\text { sesuai saran } \\
\text { ahli materi }\end{array}$ \\
\cline { 3 - 5 }
\end{tabular}

Revisi dilakukan berdasarkan komentar dan saran dari para ahli. Bagian-bagian yang direvisi berdasarkan hasil validasi dapat dilihat pada Tabel 12 berikut orang validator materi, dan dua orang validator media. Keempat validator tersebut memberikan penilaian kedalam angket kelayakan buku kerja yang telah persiapkan oleh peneliti. Data hasil validasi materi buku kerja media pembelajaran berbasis kontekstual dapat dilihat pada tabel 10 sebagai berikut: 


\begin{tabular}{|c|c|c|c|c|}
\hline Nama Ahli & Bab ke & $\begin{array}{l}\text { Bagian yang } \\
\text { Direvisi }\end{array}$ & Deskripsi & $\begin{array}{c}\text { Hasil } \\
\text { Perbaikan }\end{array}$ \\
\hline & & & lingkungan kontekstual & \\
\hline $\begin{array}{l}\text { Ahli Materi Pembelajaran } \\
\text { Kontekstual (Ratih Yuniastri, } \\
\text { S.Si., M.Pd) }\end{array}$ & 3 dan 4 & Rangkuman & $\begin{array}{l}\text { Bagian rangkuman perlu } \\
\text { ditambahkan referensi }\end{array}$ & $\begin{array}{c}\text { Diperbaiki } \\
\text { sesuai saran } \\
\text { ahli materi }\end{array}$ \\
\hline $\begin{array}{l}\text { Ahli Desain } 1 \text { (Sri Wahyuni, } \\
\text { S.Pd., M.Pd.) }\end{array}$ & & Sampul & $\begin{array}{l}\text { Sebaiknya menggunakan gambar } \\
\text { background yang sesuai dengan } \\
\text { kontekstual IPA }\end{array}$ & $\begin{array}{l}\text { Diperbaiki } \\
\text { sesuai saran } \\
\text { ahli desain }\end{array}$ \\
\hline \multirow[t]{2}{*}{ Nur Khamimah, S.Pd., M.Pd. } & & Sampul & $\begin{array}{l}\text { Judul buku kerja ditambahkan } \\
\text { IPA dan diperkecil, gambar di } \\
\text { sesuaikam dengan judul buku } \\
\text { kerja kontekstual }\end{array}$ & \multirow{2}{*}{$\begin{array}{l}\text { Diperbaiki } \\
\text { sesuai saran } \\
\text { ahli desain }\end{array}$} \\
\hline & & Tulisan & $\begin{array}{l}\text { Judul/tulisan yang menjadi } \\
\text { perhatian diberi penekanan } \\
\text { dengan warna yang berbeda atau } \\
\text { bold; } \\
\text { Teks biasa berwarna hitam }\end{array}$ & \\
\hline
\end{tabular}

Sumber: Peneliti, diolah pada September 2019

Saran dan komentar dari para ahli menjadi masukan yang kemudian dilakukan perbaikan terhadap produk petunjuk praktikum IPA berbasis lingkungan masyarakat pesisir yang dikembangkan. Tabel 13 menunjukkan hasil perbaikan dari revisi atau saran ahli.

Tabel 13 Produk Sebelum dan Sesudah Revisi

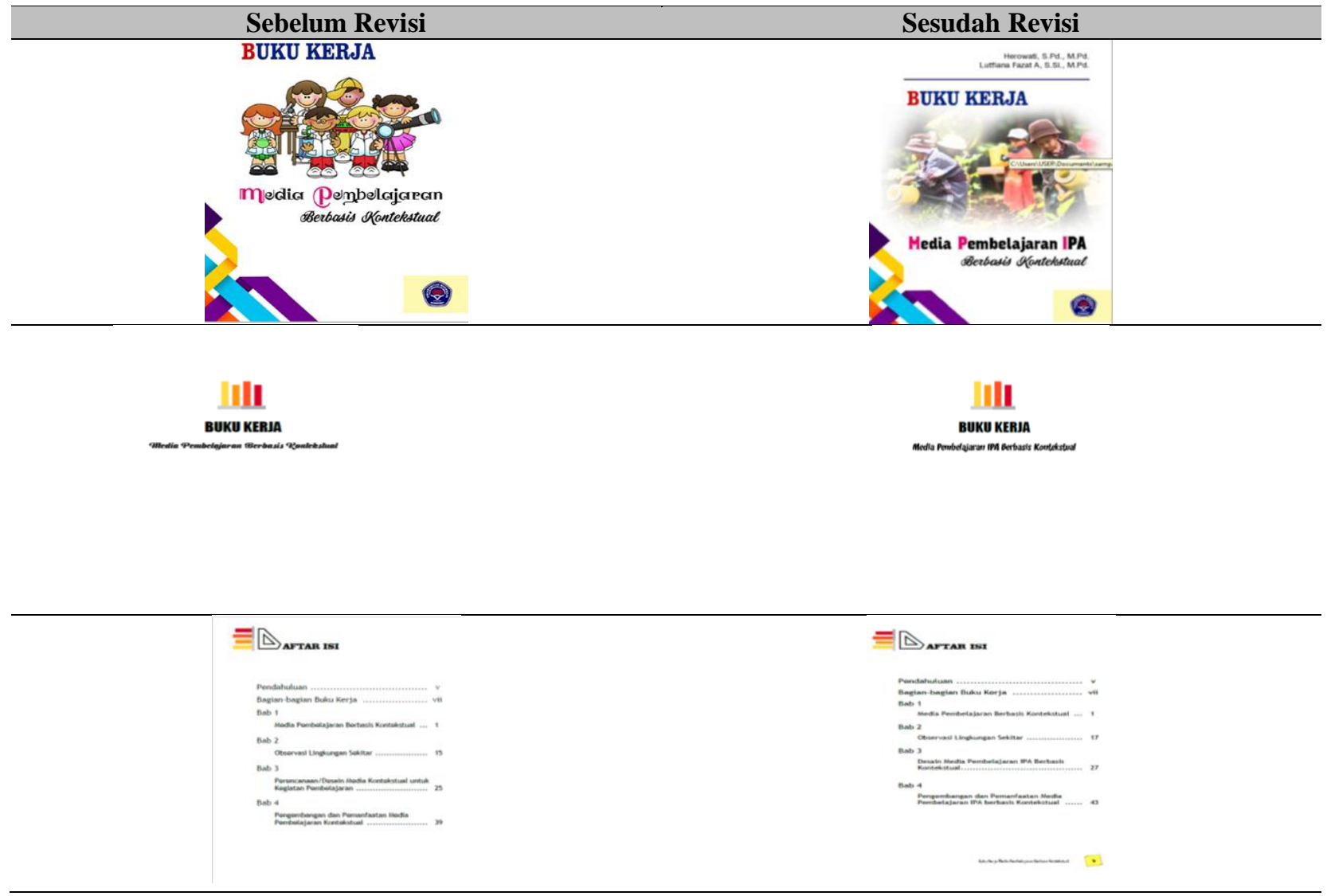




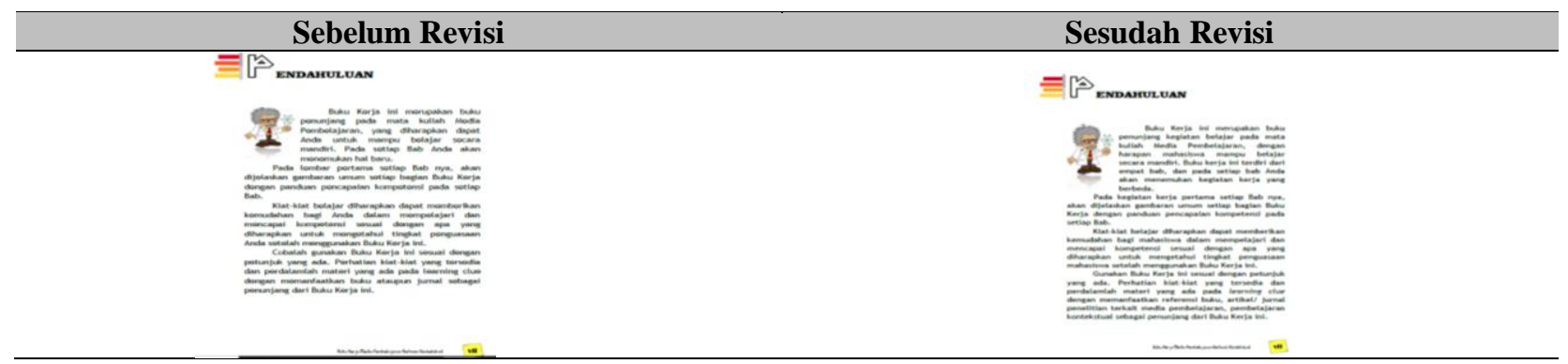

Sumber: Peneliti, diolah pada September 2019

\section{Data Hasil Respon Produk}

Data hasil uji coba awal adalah hasil wawancara mahasiswa mengenai produk buku kerja media pembelajaran IPA berbasis kontekstual secara umum. Sedangkan untuk uji coba kuantitatif data yang diperoleh yaitu respon mahasiswa melalui sebaran angket. Data-data yang dihasilkan dalam uji coba akan digunakan untuk memperbaiki serta menyempurnakan produk.

Penyajian Data Uji Coba Awal (Initial Testing). Tahap uji coba awal dilakukan dengan teknik wawancara pada 5 orang mahasiswa semester III program studi pendidikan IPA Universitas Wiraraja pada tanggal 30 September 2019. Hasil wawancara didapatkan informasi bahwa (1) mahasiswa menyatakan tahapan kegiatan pada buku kerja tersusun secara sistematis, (2) mahasiswa menyatakan tahapan kegiatan pada buku kerja sangat membantu untuk kegiatan pengembangan media pembelajaran IPA yang berbsis kontekstual, (3) mahasiswa menyatakan tampilan buku kerja yang dikembangkan menarik.

Penyajian Data Uji Coba Kuantitatif (Quantitative Testing). Tahap uji coba kuantitatif dilakukan dengan teknik penyebaran angket semester III program studi pendidikan IPA Universitas Wiraraja pada tanggal 30 September 2019. Hasil respon mahasiswa dapat dilihat pada Gambar 1 berikut.

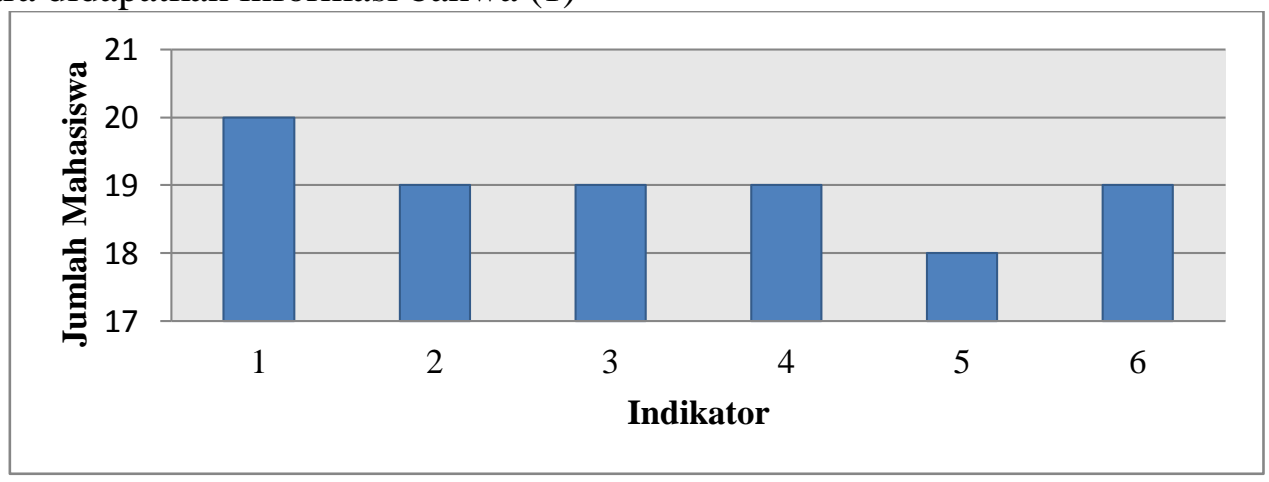

Gambar 1. Data Respon Mahasiswa pada Uji Coba Kuantitatif

Keterangan:

1. Gambar yang digunakan memperjelas materi media pembelajaran IPA

2. Contoh yang digunakan mudah ditemui dalam kehidupan sehari-hari (kontekstual)

3. Penyajian materi pada buku kerja media pembelajaran IPA berbasis kontektstual sistematis

4. Bahasa yang digunakan mudah dipahami Bahasa yang digunakan mudah dipahami

5. Tampilan materi pada buku kerja media pembelajaran IPA berbasis kontektstual menarik 
6. Petunjuk praktikum materi pada buku kerja media pembelajaran IPA berbasis kontektstual mudah dibawa

Gambar 1 menunjukkan respon mahasiswa terhadap buku kerja media pembelajaran IPA berbasis kontektstual adalah positif, karena persentase nilai yang diperoleh pada tiap indikator yaitu $95 \%$ dengan kriteria sangat baik.

\section{PEMBAHASAN}

Pembahasan dalam peneitian :ini mengenai: (1) kelayakan buku kerja media pembelajaran berbasis kontekstual, dan (2) respon mahasiswa terhadap design buku kerja media pembelajaran berbasis kontekstual.

\section{Kelayakan Buku kerja media pembelajaran berbasis kontekstual}

Kelayakan buku kerja media pembelajaran berbasis kontekstual dilakukan dengan uji kelayakan validasi oleh para ahli. Kegiatan validasi dilakukan untuk mengetahui kelayakan dari pengembangan yang dilakukan (Prabowo, Ibrohim and Saptasari, 2016). Buku kerja media pembelajaran berbasis kontekstual dilakukan uji kelayakan berdasarkan aspek kualitas isi divalidasi oleh ahli materi, dan aspek desain divalidasi oleh ahli desain. Aspek materi terdiri dari 10 indikator yaitu: materi sesuai dengan capaian pembelajaran mata kuliah media pembelajaran; Materi sesuai dengan capaian akhir perkuliahan Kompetensi mata kuliah media pembelajaran; Materi mencerminkan jabaran capaian akhir perkuliahan mata kuliah media pembelajaran pada indicator merancang, memilih dan memproduksi media pembelajaran IPA dengan memanfaatkan lingkungan sekitar (kontekstual); Materi meliputi bidang kajian media pembelajaran untuk pembelajaran IPA berbasis kontekstual; Kegiatan pada buku kerja sesuai dengan lingkungan sekitar (kontekstual); Langkah kerja jelas dan sistematis; Kalimat memiliki struktur S-P-O-K (subjek- predikat-objek-keterangan); Sesuai dengan kaidah Bahasa Indonesia; Kalimat tidak ambigu; Konsisten dalam menulis kata dan pada aspek desain terdiri dari 10 indikator yaitu: Gambar sampul sesuai dengan judul buku kerja media pembelajaran berbasis kontekstual; Judul buku menjadi pusat pandang; Warna tulisan judul buku kontras dengan warna background ; Penempatan gambar tidak mengganggu tulisan ; Penggunaan variasi huruf (bold, italic, all capital, small capital) konsisten ; Spasi teks konsisten ; Ukuran gambar sesuai dengan resolusi ; Gambar memuat nomor dan judul ; Warna gambar realistis ; Bentuk gambar realistis Lembar validasi digunakan untuk mendapatkan data kelayakan buku kerja yang dikembangkan.

Kelayakan buku kerja media pembelajaran berbasis kontekstual berdasarkan penilaian oleh ahli materi dan ahli desain, hasil yang diperoleh untuk kelayakan pada aspek materi memperoleh persentase sebesar 96\% dengan kriteria sangat layak. Adapun pada aspek desain memperoleh persentase sebesar $98 \%$ dengan kriteria sangat layak. Berdasarkan nilai tersebut, dapat diketahui bahwa buku kerja media pembelajaran berbasis kontekstual dikatakan sangat layak dan dapat digunakan dalam pembelajaran. Kelayakan tersebut sesuai dengan pernyataan (Setiawan and Wiyardi, 2015) yang menyatakan bahwa suatu produk yang dikembangkan dikatakan sangat layak jika mendapatkan nilai klasifikasi $81 \%$ sampai $100 \%$.

Buku kerja media pembelajaran kontekstual dirancang inovatif dan menyenangkan serta mudah digunakan dan mudah dipelajari. Materi dirancang dengan latihan berupa soal-soal yang berbeda-beda pada setiap babnya terdiri dari empat bab dengan judul kegiatan pada setiap bab nya adalah bab 1 media pembelajaran berbasis 
kontekstual, bab 2 observasi lingkungan sekitar, bab. 3 desain media pembelajaran IPA berbasis kontekstual, dan bab. 4 pengembangan dan pemanfaatan media pembelajaran IPA berbasis kontekstual. Karakteristik dari buku kerja media pembelajaran berbasis kontekstual yaitu pada bagian kegiatan studi kasus, studi kasus yang diangkat dalam buku kerja merupakan kasus yang terjadi di lingkungan mahasiswa. Adanya kesinambungan antara bab satu dengan bab selanjutnya diharapkan mahasiswa lebih memahami materi serta dapat menghasilkan produk media pembelajaran IPA yang berbasis kontekstual. Buku kerja menggunakan bahasa yang mudah dipahami dengan bahasa sehari-hari serta adanya petunjuk awal bagi mahasiswa dalam mencari berbagai literature yang relevan dengan kegiatan yang akan dilakukan. Bahasa adalah bentuk komunikasi, entah itu lisan, tertulis atau tanda, yang didasarkan pada sistem simbol. Menurut Vygotsky, bahasa memiliki peranan kuat dalam membentuk pemikiran. Perkembangan memori melibatkan mahasiswa lebih memahami materi. Menurut teori pemprosesan informasi, suatu informasi dapat bertahan dalam memori jangka panjang (ingatan) jika diulangi terus-menerus atau digunakan dalam suatu aktivitas (Santrock, 2010). Validasi aspek bahasa memiliki tujuan untuk mengetahui kesesuaian dan ketepatan tata bahasa yang digunakan dalam produk yang dikembangkan (Setiawati, Rahayu and Setiadi, 2017).

Menurut (Habibi, Anekawati and Wati, 2012) Pembelajaran yang disajikan berdasarkan kultur dan kondisi lingkungan mahasiswa sehari-hari akan lebih memberi pemahaman yang mendalam. Lingkungan masyarakat yang dimanfaatkan dalam kegiatan pembelajaran dapat menjadikan proses pembelajaran lebih bermakna sehingga mahasiswa mampu mengaitkan antara materi dengan fakta di lingkungannya. Menurut teori belajar bermakna Ausubel, proses lebih bermakna jika mahasiswa membangun konsep dalam dirinya dengan menghubungkan pengalaman, fenomena-fenomena yang mahasiswa jumpai dengan konsep IPA (Wisudawati and Sulistyowati, 2014). Hal ini dapat ditemukan dalam buku kerja media pembelajaran berbasis kontekstual dimana mahasiswa melakukan observasi untuk mengetahui keadaan yang terjadi di lingkungan sekitarnya. Kegiatan observasi dilakukan di sekolah dan lingkungan sekitar mahasiswa. Hasil observasi akan dijadikan sebagai pedoman yang nantinya dikaitkan dengan teori yang telah dimiliki mahasiswa untuk dikaji ulang dan menyelesaikan masalah yang terjadi. Konsep tersebut tentu berhubungan dengan pengalaman dan fenomena yang mahasiswa hadapi secara berulang sehingga mahasiswa dapat mengungat dengan baik. Komponen dalam buku kerja media pembelajaran berbasis kontekstual sesuai dengan komponen yang ada dalam pembelajaran kontekstual seperti kontruktivisme, menemukan, bertanya, masyarakat belajar, pemodelan, refleksi, penilaian autentik (Suprijono, 2009).

Validasi desain untuk mengetahui kelayakan desain dari buku kerja yang dikembangkan. Validasi desain meliputi tata letak, tanda baca, jenis dan ukuran huruf, sampul, dan desain secara umum. Menurut (Sari, 2015) menyatakan bahwa bahan ajar cetak haruslah memperhatikan beberapah hal dan salah satunya yaitu kemudahan dibaca. Kemudahan dibaca ini menyangkut jenis huruf yang digunakan, ukuran teks, serta mudah dibaca.

Berdasarkan validasi dari para ahli yang sesuai dengan bidangnya maka tampilan buku kerja media pembelajaran berbasis kontekstual berada pada kategori sangat layak. Kelayakan tersebut sesuai dengan pernyataan (Setiawan and Wiyardi, 
2015) yang menyatakan bahwa suatu produk yang dikembangkan dikatakan sangat layak jika mendapatkan nilai klasifikasi $81 \%$ sampai $100 \%$. (Suhana, 2014) memaparkan bahwa buku kerja yang dikembangkan haruslah dikemas dan disajikan secara menarik agara dapat membangun minat dan motivasi mahasiswa untuk belajar. Hal ini dapat diartikan bahwa tampilan sebuah bahan ajar memiliki peran penting untuk meningkatkan motivasi belajar mahasiswa dalam mempelajari materi. Hasil penilaian validasi yang diperoleh dari materi dan desain buku kerja media pembelajaran berbasis kontekstual berada pada kategori sangat layak dikarenakan dengan beberapa revisi yang diperlukan. Buku kerja yang dikembangkan telah melalui revisi sehingga mendapatkan hasil sangat layak dengan persentase validasi materi dan desain secara bertutut-turut adala $96 \%$ dan $98 \%$.

\section{Respon mahasiswa terhadap desain buku kerja media pembelajaran berbasis kontekstual}

Respon mahasiswa dalam penelitian ini berupa hasil penilaian mahasiswa terhadap produk yaitu melihat tampilan produk. Pengamatan tersebut akan meninggalkan kesan dalam diri mahasiswa. Oleh karena itu, selain meminta penilaian dalam bentuk skala Guttman dengan 2 opsi jawaban yaitu ya dan tidak. Angket respon mahasiswa yang diberikan terdiri dari 6 kalimat menyesuaikan terhadap desain buku kerja yang dikembangkan. Mahasiswa juga diminta memberikan komentar atau saran untuk mengetahui seperti apa kesan mereka terhadap buku kerja media pembelajaran berbasis kontekstual. Berdasarkan hasil angket didapat bahwa tampilan atau desain dari buku kerja yang dikembangkan memperoleh 95\% dengan kategori sangat baik.
Menurut Piaget, tenaga pendidik harus memberikan dukungan mahasiswa mengeksplorasi dan menemukan pengetahuannya sendiri. Buku kerja yang dikembangkan dikaitkan dengan lingkungan mahasiswa, hal ini berkaitan dengan pengetahuan yang mahasiswa peroleh sebelumnya dari pengalaman tidak jauh berbeda dengan pengetahuan yang mereka dapatkan dari produk yang dikembangkan. Seperti yang dikemukakan oleh (Widiadnyana, Sadia and Suastra, 2014) interaksi dengan lingkungan dapat memperbaiki pemahaman dan memperkaya pengetahuan. Oleh karena itu, mahasiswa akan merasa lebih mudah mengerti terhadap produk karena dikaitkan dengan lingkungan tempat tinggalnya.

Respon mahasiswa pada pada uji coba kuantitatif adalah respon positif. Selain karena banyak yang memberikan jawaban iya, juga memberikan komentar yang positif sepeti buku kerja menarik. Tampilan produk yang dikembangkan baik dari segi pewarnaan mendapat respon positif yang ditunjukan dengan indikator tampilan menarik, kombinasi warna, serta peletakkan gambar yang sesuai. Perpaduan warna yang digunakan pada buku kerja media pembelajaran berbasis kontekstual memiliki peran agar pada saat pembaca melihat warna-warna yang ada pada produk yang dikembangkan akan menimbulkan nyaman untuk dipandang atau dilihat karena pada dasarnya warna dapat digunakan sebagai alat untuk mengekspresikan emosi dari seseorang (Yogananti, 2015) Warna yang digunakan pada penelitian ini yaitu berbagai jenis warna yang dikombinasikan untuk mempengaruhi mahasiswa agar lebih mengingat kata dan petunjuk yang ada. Menurut (Olurinola and Tayo, 2015) menjelaskan bahwa warna dapat mempengaruhi cara melihat serta memproses informasi seseorang sehingga dapat meningkatkan kemampuan dalam 
mengingat kata maupun gambar.Rata-rata mahasiswa menyatakan bahwa buku kerja media pembelajaran berbasis kontekstual ini bagus. Hal tersebut sejalan dengan fungsi yang dikemukakan oleh (Waluyo and Parmin, 2014) bahwa petunjuk praktikum bertujuan untuk memperlancar dan memberikan materi pembelajaran sebagai pegangan bagi mahasiswa dalam melaksanakan kegiatan praktikum. Seperti halnya buku kerja media pembelajaran berbasis kontekstual ini yang dibuat dalam rangka untuk memudahkan mahasiswa dalam melakukan praktikum dan membantu mahasiswa memahami kegiatan praktikum yang akan dilakukan dengan memanafaatkan lingkungan disekitar mahasiswa.

\section{PENUTUP}

\section{Simpulan}

Berdasarkan hasil penelitian yang dilakukan dapat disimpulkan bahwa: Kelayakan buku kerja media pembelajaran IPA berbasis kontekstual didapatkan dari validasi aspek materi $96 \%$ dan desain memperoleh rata-rata persentase $98 \%$ dengan kategori sangat layak sehingga buku kerja media pembelajaran IPA berbasis kontekstual dapat digunakan..

\section{Keterbatasan Penelitian}

Keterbatasan penelitian atas pengembangan buku kerja media pembelajaran IPA berbasis kontekstual adalah belum diadakannya uji coba keterbacaan produk yang telah dikembangkan dikarenakan keterbatasan waktu penelitian sampai dengan bulan oktober sedangkan kegiatan perkuliahan media pembelajaran masih berjalan lima kali pertemuan.

\section{Rekomendasi}

Rekomendasi atas pengembangan buku kerja media pembelajaran IPA berbasis kontekstual yaitu (1) uji coba keterbacaan dari produk buku kerja media pembelajaran IPA berbasis kontekstual, dan (2) pengembangan lanjutan buku kerja media pembelajaran IPA berbasis TIK.

\section{DAFTAR PUSTAKA}

Darmawan, Deni. (2014) Metode Penelitian Kuantitatif. Cetakan Kedua. Bandung: PT. Remaja Rosdakarya.

Darman, R. D. Wibowo F. C., Putra A., dan Hasra A. (2017)

'Pengembangan Buku Kerja Fisika Berbasis Kontekstual pada Konsep Suhu dan Kalor, Jurnal Gravity: Jurnal Ilmiah Penelitian dan Pembelajaran Fisika, 3(2), pp. 120123. Available at: http://jurnal.untirta.ac.id/index.php/ Gravity.

Dwiyogo, Wasis. (2013). Media Pembelajaran. Malang. Wineka Media.

Habibi, Anekawati, A. and Wati, H. D. (2012) Pembelajaran IPA Berbasis Kultur Masyarakat Pesisir. Sumenep: FKIP Press.

Hanafiah dan Suhana, (2010) Konsep Strategi Pembelajaran. Bandung: PTRefika Aditama.

Maudiarti, Santi. dkk. 2007. Prisip Disain Pembelajaran: Buku Kerja. Jakarta : Kencana.

Mujiono, Puji. 2007. Kegiatan penilaian Buku Teks Pelajaran Pendidikan Dasar dan Menengah. Buletin $B S N P, 1(2)$, pp 14-23. Available at: http://www.bsnp-indonesia.org. (Accessed: 15 April 2019).

Prabowo, C. A., Ibrohim and Saptasari, M. (2016) 'Pengembangan Modul Pembelajaran Inkuiri Berbasis Laboratorium Virtual', Jurnal Pendidikan, 1(6), pp. 1090-1097. Available at: http://journal.um.ac.id/index.php/jpt pp/article/view/7213/3212. 
Santrock, J. W. (2010) Psikologi Pendidikan. 2nd edn. Jakarta: Kencana Prenada Media.

Sari, V. K. (2015) Pengembangan Bahan Ajar Berbasis Cerita Bergambar untuk Meningkatkan Pemahaman Konsep pada Subtema 2 Lingkungan Sekitar Rumahku Kelas I SDN Genukwatu IV Ngoro Jombang. Universitas Islam Negeri Maulana Malik Ibrahim Malang. Available at: etheses.uinmalang.ac.id/5533/1/11140069.pdf.

Setiawan, H. W. and Wiyardi, R. S. (2015) 'Penggunaan App Inventor dalam Pembuatan Game Education Berbasis Android Sebagai Media Pembelajaran yang Mandiri dan Interaktif Untuk Meningkatkan Hasil Belajar Siswa TITL Pada Pembelajaran Listrik Dasar SMK Muhammadiyah Majenang', Edu Elektrika Journal, 4(1). Available at:

https://journal.unnes.ac.id/sju/index .php/eduel/article/view/7781

(Accessed: 24 July 2019).

Suprijono, A. (2009) Cooperative Learning Teori dan Aplikasi Paikem. Yogyakarta: Pustaka Pelajar.

Thiagarajan, S., Semmel, D. S. and Semmel, M. I. (1974) Instructional Development for Training Teachers of Exceptional Children: A Sourcebook. Available at: https://files.eric.ed.gov/fulltext/ED0 90725.pdf (Accessed: 19 May 2019).

Waluyo, M. E. and Parmin, P. (2014) 'Pengembangan Panduan Praktikum IPA Terpadu Berbasis Inkuiri Terbimbing Tema Fotosintesis untuk Menumbuhkan Keterampilan Kerja Ilmiah Siswa SMP', Unnes Science Education Journal, 3(3), pp. 677-684. Available https://journal.unnes.ac.id/sju/index .php/usej/article/view/4286

(Accessed: 29 March 2019).

Widiadnyana, I. W., Sadia, W. and Suastra, W. (2014) 'Pengaruh Model Discovery Learning Terhadap Pemahaman Konsep IPA dan Sikap Ilmiah Siswa SMP', Jurnal Pendidikan dan Pembelajaran IPA Indonesia, 4(1). Available at: http://119.252.161.254/ejournal/index.php/jurnal_ipa/article/ view/1344 (Accessed: 16 August 2019).

Wisudawati, A. W. and Sulistyowati, E. (2014) Metodologi Pembelajaran IPA. Jakarta: Bumi Aksara.

Wulandari, Y. (2017) 'KELAYAKAN ASPEK MATERI DAN MEDIA DALAM PENGEMBANGAN BUKU AJAR SASTRA LAMA', Gramatika STKIP PGRI Sumatera Barat, 3(2). doi: 10.22202/jg.2017.v3i2.2049.

Yogananti, A. F. (2015) 'Pengaruh Psikologi Kombinasi Warna dalam Website', Jurnal Desain Komunikasi Visual \& Multimedia, 1(1), pp. 45-54. Available at: https://publikasi.dinus.ac.id/index.p $\mathrm{hp} /$ andharupa/article/view/956. 